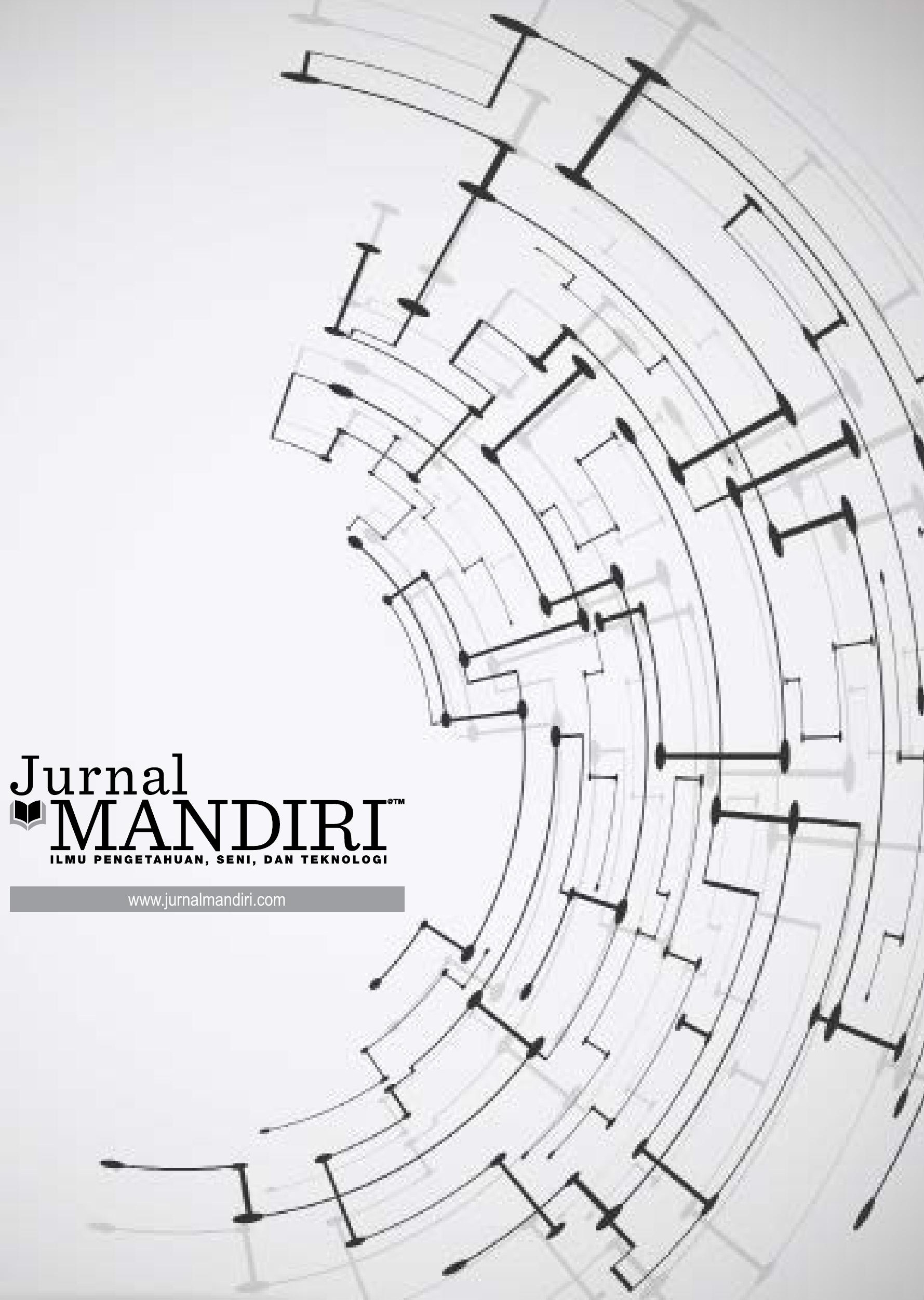


ISSN : 2580-3220, E-ISSN : 2580-4588

J. Mandiri., Vol. 1, No. 1, Juni 2017 (85 - 97)

(C)2017 Lembaga Kajian Demokrasi

dan Pemberdayaan Masyarakat (LKD-PM)

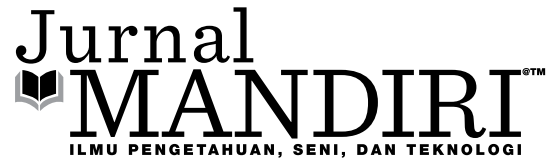

\title{
PENGEMBANGAN MODUL PEMBELAJARAN EKONOMI BERBASIS GUIDED INQUIRY UNTUK MENINGKATKAN HASIL BELAJAR EKONOMI SISWA KELAS X SMA MUHAMMADIYAH 1 KARANGANYAR
}

\author{
Kusworo \\ Universitas Pamulang \\ kusworo1991@gmail.com
}

\begin{abstract}
ABSTRAK
Penelitian ini bertujuan untuk (1) menganalisis pengembangan modul pembelajaran ekonomi berbasis guided inquiry untuk meningkatkan hasil belajar siswa kelas X SMA Muhammadiyah 1 Karanganyar, (2) menganalisis keefektifan penggunaan pembelajaran ekonomi berbasis guided inquiry untuk meningkatkan hasil belajar siswa kelas X SMA Muhammadiyah 1 Karanganyar. Penelitian pengembangan modul pembelajaran ekonomi ini menggunakan prosedur Borg and Gall yang dimodifikasi menjadi 8 tahap. Analis data yang digunakan selama pengembangan adalah analisis deskriptif, analisis kelayakan modul berdasarkan skor kriteria, dan analisis hasil belajar siswa menggunakan $t$-test. Berdasarkan hasil analisis deskriptif modul pembelajaran ekonomi berbasis guided inquiry disimpulkan bahwa validasi ahli media sebanyak 98,28\% dengan kriteria sangat baik, ahli materi 95,90\% dengan kriteria sangat baik, dan ahli praktisi sebanyak 95,90\% dengan kriteria sangat baik. Berdasarkan hasil analisis uji keefektifan dengan menggunakan software IBM SPSS 17 dengan rumus t-test, nilai thitung yang didapatkan dari posttest kelas kontrol dan eksperimen adalah 7,853 dengan nilai $t_{\text {tabel }}$ adalah 1.980, dengan demikian $t_{\text {hitung }}>$ $t_{\text {tabel }}$ yang berarti peningkatan nilai hasil belajar ekonomi kelas eksperimen lebih baik dari pada kelas kontrol. Selanjutnya, didapatkan nilai signifikansi sebesar $0,000<\alpha(0,05)$, yang menunjukkan bahwa H1 diterima berarti kelas eksperimen lebih baik daripada kelas kontrol. Hal ini menunjukkan bahwa modul pembelajaran ekonomi berbasis hasil pengembangan lebih meningkatkan hasil belajar ekonomi siswa dibandingkan tanpa menggunakan modul pembelajaran berbasis guided inquiry. Kesimpulan. Kesimpulannya adalah modul pembelajaran ekonomi berbasis ekonomi berbasis guided inquiry valid dan efektif digunakan untuk meningkatkan hasil belajar siswa.
\end{abstract}

Kata kunci: pengembangan modul, guided inquiry, hasil belajar.

\section{PENDAHULUAN}

\section{Latar Belakang}

Pendidikan memiliki peran penting dalam pembangunan nasional karena sasaran dari pendidikan yaitu berupaya dalam meningkatkan kualitas Sumber Daya Manusia
(SDM). Pembangunan nasional semata-mata bukan hanya pembangunan dalam bentuk pembangunan fisik, akan tetapi yang terpenting yaitu pembangunan spiritual dan emosional yang secara bulat diartikan dalam pembangunan manusia yang menjadi tugas utama bagi pen- 
didikan. Selain itu, pendidikan juga lebih menekankan dalam meningkatkan SDM yang berkualitas yang memiliki ilmu pengetahuan, keterampilan, berbudi pekerti luhur, berakhlak mulia serta bertanggung jawab dalam upaya peningkatan kesejahteraan diri pada khususnya serta masyarakat dan negara pada umumnya. Oleh karena itu, perlunya peningkatan kualitas pendidikan dalam upaya meningkatkan pembangunan nasional.

Pembaharuan dan perbaikan dalam bidang pendidikan dilakukan dalam upaya peningkatan kualitas pendidikan seiring dengan kebutuhan zaman. Upaya tersebut dilakukan agar terwujudnya tujuan dari pendidikan yaitu untuk meningkatkan kualitas SDM agar mampu mengembangkan potensi yang dimiliki secara optimal. Tujuan dari pendidikan ini seperti tertuang dalam Pasal 1, Undang-Undang Nomor 20 Tahun 2003, Tentang Sistem Pendidikan Nasional yaitu.

Pendidikan adalah usaha sadar terencana untuk mewujudkan suasana belajar dan proses pembelajaran agar siswa dapat secara aktif mengembangkan potensi dirinya untuk memiliki kekuatan spiritual keagamaan, pengendalian diri, kepribadian, kecerdasan, akhlak mulia, serta keterampilan yang diperlukan dirinya, masyarakat, bangsa, dan negara.

Pendidikan juga berperan penting dalam mengembangkan potensi manusia yaitu berupa kualitas diri manusia. Hal ini seperti tertuang dalam BAB II Pasal 3, Undang-Undang Nomor 20 Tahun 2003 tentang Sistem Pendidikan Nasional, yang menyebutkan bahwa pendidikan nasional berfungsi mengembangkan kemampuan dan membentuk watak serta peradaban bangsa serta bertujuan untuk mengembangkan potensi siswa agar menjadi manusia yang beriman dan bertaqwa kepada Tuhan Yang Maha Esa, berakhlak mulia, sehat, berilmu, cakap, kreatif, mandiri, dan menjadi warga negara yang demokratis serta bertanggung jawab. Oleh karena itu, fungsi pendidikan memberikan dampak dalam meningkatkan kualitas diri siswa melalui proses pembelajaran di sekolah. Upaya dalam mengevaluasi proses pembelajaran yaitu melalui pengetahuan dan kemampuan yang dimiliki siswa dari peningkatan hasil belajar.

Berdasarkan studi pendahuluan yang telah dilakukan pada siswa kelas X SMA Muhammadiyah 1 Karanganyar tahun pelajaran 2015/2016, didapatkan hasil belajar siswa yang belum memuaskan. Hal ini dapat dilihat dari hasil ujian semester ganjil tahun pelajaran 2015/2016. Hasil belajar rata-rata yang diraih oleh siswa kelas X SMA Muhammadiyah masih belum optimal dan tergolong rendah. Persentase rata-rata hasil belajar siswa menunjukkan bahwa nilai hasil ujian semester ganjil tahun pelajaran 2015/2016 masih di bawah nilai Kriteria Ketuntasan Minimum (KKM) yaitu 70. Persentase hasil belajar siswa yang mencapai nilai di atas KKM atau $\geq 70$ yaitu $13,90 \%$ yang berjumlah 77 siswa dan sisanya $86,10 \%$ yang berjumlah 477 siswa masih di bawah nilai KKM dengan total siswa berjumlah 554 siswa, hal ini berarti hasil belajar siswa masih tergolong rendah.

Berdasarkan pra penelitian di SMA Muhammadiyah 1 Karanganyar, melalui wawancara guru, bahwa bahan ajar yang digunakan oleh siswa hanya berupa Lembar Kerja Siswa (LKS). Siswa tidak diberikan bahan ajar lain seperti modul, buku paket, handout, brosur, dan leaflet sebagai sumber belajar dalam kegiatan belajar siswa. LKS juga belum bisa mengembangkan diri siswa dalam mengembangkan pengetahuan dan keterampilan berpikir sehingga siswa masih kesulitan dalam menyelesaikan persoalan yang diajukan kepadanya. Siswa juga masih ketergantungan terhadap siswa yang lain dalam kegiatan belajar. Selain itu, terdapat beberapa kelemahan yang dimiliki oleh LKS, yaitu LKS kurang menarik karena dicetak menggunakan kertas buram dan hanya terdapat warna pada sampul, materi yang disajikan masih terlalu banyak dengan penjelasan yang kurang terarah pada topik bahasan, bahasa yang digunakan membuat siswa sulit memahaminya, terdapat banyak soal baik pilihan ganda dan uraian 
yang hanya melatihkan segi kognitif siswa, sehingga keterampilan berpikir siswa belum dapat terpenuhi, dan tidak adanya peta konsep. Oleh karena itu, diperlukan sumber belajar lain yang mampu meningkatkan pemahaman dan kemampuan berpikir siswa dalam mempelajari materi pelajaran. Salah satu sumber belajar tersebut yaitu modul pembelajaran yang mampu memberikan kesempatan kepada siswa dalam mengembangkan pengetahuan dan keterampilan dalam menyerap materi pelajaran dalam modul.

Bahan ajar berupa modul dapat memberikan pengalaman dalam belajar yang direncanakan dan dirancang secara sistematis untuk mencapai tujuan belajar. Perencanaan dan perancangan modul harus merangsang siswa agar secara aktif memiliki keinginan untuk mempelajari materi modul tersebut dalam kegiatan belajar di kelas. Kegiatan belajar mengajar yang dilakukan oleh guru dan siswa merupakan suatu proses interaksi edukatif, dimana terjalin komunikasi timbal balik yang memiliki tujuan dalam menyalurkan dan menerima ilmu pengetahuan dalam mengembangkan pengetahuan dan keterampilan siswa. Interaksi edukatif ini dilakukan antara guru dengan siswa, siswa dengan siswa yang lain, serta siswa dengan sumber belajar.

Berdasarkan hasil wawancara yang dilakukan terhadap guru dan wakil kepala sekolah bidang kurikulum di SMA Muhammadiyah 1 Karanganyar, bahwa diketahui belum ada bahan ajar berupa modul sebagai salah satu sumber belajar siswa. Modul pembelajaran merupakan sumber informasi yang berisi materi-materi yang harus dipelajari dan dikuasai oleh siswa. Modul pembelajaran juga menampilkan sosok utuh dari kompetensi yang nantinya akan dikuasai siswa dalam kegiatan belajarnya. Keberadaan modul pembelajaran sangat penting dalam menunjang keberhasilan belajar siswa. Oleh karena itu, diperlukan modul pembelajaran agar membuat siswa tertarik untuk mempelajari dan menguasai materi pelajaran sebagai upaya dalam peningkatan kualitas pembelajaran yang akan berakibat pada peningkatan hasil belajar siswa.
Proses pembelajaran harus mengintegrasikan bahan ajar dengan strategi pembelajaran yang dilakukan oleh guru sebagai peningkatan keaktifan siswa dalam menyerap ilmu pengetahuan. Bahan ajar yang diintegrasikan dengan strategi pembelajaran yang sesuai akan membuat pembelajaran lebih aktif, menarik, dan menyenangkan yang membuat siswa lebih fokus dalam mengikuti pembelajaran. Hal ini bertolak belakang dengan situasi dalam proses pembelajaran di SMA Muhammadiyah 1 Karanganyar. Berdasarkan hasil wawancara yang dilakukan kepada wakil kepala sekolah bidang kurikulum dan beberapa guru ekonomi di SMA Muhammadiyah 1 Karanganyar menunjukkan bahwa guru tidak mengikuti perkembangan zaman yang saat ini pembelajaran sudah berorientasi pada siswa bukan berorientasi pada guru. Guru juga belum memahami modelmodel pembelajaran yang berorientasi pada siswa, dimana siswa secara aktif mengikuti pembelajaran di kelas. Guru ekonomi dalam proses pembelajaran masih menggunakan metode belajar yang monoton, selama ini guru ekonomi masih menggunakan metode ceramah. Padahal metode ceramah membuat materi pembelajaran yang disampaikan oleh guru tidak semua dapat diserap oleh siswa dengan baik dan optimal dalam kegiatan belajarnya. Pembelajaran yang disampaikan oleh guru juga membuat siswa pasif dalam pembelajaran di kelas. Kurangnya motivasi guru dalam mempelajari modelmodel pembelajaran yang memberikan siswa aktif dalam belajar membuat pembelajaran membosankan bagi siswa. Oleh karena itu, untuk menghindarinya maka guru harus kreatif dalam menyusun strategi pembelajaran dengan memanfaatkan media dan sumber belajar. Guru dapat menggunakan sumber belajar yang diintegerasikan dengan strategi pembelajaran untuk memberikan daya tarik berupa keingintahuan siswa untuk mempelajari materi pelajaran dan memberikan keaktifan siswa dalam belajar.

Pengembangan modul pembelajaran de- 
ngan pendekatan guided inquiry dalam pembelajaran ekonomi di SMA, bertujuan untuk menumbuhkan kemampuan berpikir dalam meningkatkan rasa ingin tahu siswa untuk menguasai materi pelajaran. Pengembangan modul pembelajaran dengan diintegrasikan model pembelajaran dapat memberikan sumber belajar yang inovatif bagi siswa, sehingga pembelajaran lebih menarik, menyenangkan membuat siswa semangat belajar serta dapat tercapai tujuan dari pembelajaran. Hal ini didukung dengan penelitian pengembangan yang telah dilakukan oleh Ikhsan (2015) dengan judul "Pengembangan modul berbasis inkuiri terbimbing pada materi sistem gerak manusia untuk meningkatkan hasil belajar siswa kelas XI MIA SMA Negeri 1 Wera Kabupaten Bima Nusa Tenggara Barat", bahwa modul berbasis inkuiri terbimbing efektif meningkatkan hasil belajar siswa dilihat dari perbedaan hasil posttest antara kelas eksperimen dan kelas kontrol, hal ini ditunjukkan pada nilai posttest dengan Ftabel<Fhitung yaitu 2,30<24,9 dengan taraf signifikansinya 5\%. Hal ini juga didukung dengan penelitian yang telah dilakukan oleh Sen, Yilmaz, and Geban (2015) yang berjudul "The Effects Of Process Oriented Guided Inquiry Learning Environment On Students' Self-Regulated Learning Skills", bahwa proses pembelajaran yang berorientasi pada pembelajaran Guided Inquiry dapat meningkatkan pendekatan penguasaan siswa, nilai tugas, pengawasan kepercayaan untuk belajar, berpikir kritis, rekan belajar dan pembelajaran guided inquiry lebih unggul dari pembelajaran yang dirancang secara tradisional. Oleh karena itu, Kebutuhan akan pengembangan modul pembelajaran ekonomi berbasis guided inquiry sangat diperlukan untuk dilakukan pengembangan dalam upaya peningkatan hasil belajar siswa.

Berdasarkan uraian masalah tersebut, maka peneliti tertarik untuk melakukan penelitian dengan judul Pengembangan Modul Pembelajaran Ekonomi Berbasis Guided Inquiry Untuk Meningkatkan Hasil belajar Siswa Kelas X SMA Muhammadiyah 1 Karanganyar.

\section{Tujuan Pengembangan}

Tujuan pengembangan ini mengacu pada latar belakang dan rumusan masalah pengembangan. Adapun tujuan dari pengembangan ini yaitu (1) menganalisis pengembangan modul pembelajaran ekonomi berbasis guided inquiry untuk meningkatkan hasil belajar siswa kelas $\mathrm{X}$ SMA Muhammadiyah 1 Karanganyar, dan (2) menganalisis keefektifan penggunaan modul pembelajaran ekonomi berbasis guided inquiry untuk meningkatkan hasil belajar siswa kelas X SMA Muhammadiyah 1 Karanganyar.

\section{Perumusan Rumusan Masalah}

1. Bagaimanakah pengembangan modul pembelajaran ekonomi berbasis guided inquiry untuk meningkatkan hasil belajar siswa kelas X SMA Muhammadiyah 1 Karanganyar?

2. Bagaimanakah keefektifan penggunaan modul pembelajaran ekonomi berbasis guided inquiry untuk meningkatkan hasil belajar siswa kelas X SMA Muhammadiyah 1 Karanganyar?

\section{Tujuan Pengembangan}

1. Menganalisis pengembangan modul pembelajaran ekonomi berbasis guided inquiry untuk meningkatkan hasil belajar siswa kelas X SMA Muhammadiyah 1 Karanganyar.

2. Menganalisis keefektifan penggunaan modul pembelajaran ekonomi berbasis guided inquiry untuk meningkatkan hasil belajar siswa kelas X SMA Muhammadiyah 1 Karanganyar.

\section{Spesifikasi Produk yang Diharapkan}

Pengembangan modul pembelajaran ekonomi berdasarkan pada analisis kebutuhuan yang diwujudkan ke dalam pengembangan desain modul. Desain modul yang dimaksud bertujuan untuk mempermudah siswa dalam belajar, yang diharapkan dapat meningkatkan pengetahuan, hasil belajar dan kompetensi siswa, sehingga dapat memberikan manfaat dalam kehidupan sehari-hari. 
Substansi materi, penugasan, dan evaluasi di dalam modul pembelajaran ini didesain berdasarkan beberapa prinsip pembelajaran inquiry dari Hosnan (2014: 342) di antaranya berorientasi pada pengembangan intelektual, prinsip interaksi, prinsip bertanya, prinsip belajar untuk berpikir, dan prinsip keterbukaan. Modul pembelajaran ini dikemas dengan kerangka sebagai berikut: 1) halaman judul, 2) identitas modul pembelajaran, 3) kata pengantar, 4) daftar isi, 5) petunjuk penggunaan modul, 6) peta modul, 7) peta kompetensi, 8) glosarium, 9) tujuan pembelajaran, 10) deskripsi mengenai ruang lingkup materi dan tujuan mempelajari modul, 11) uraian materi, 12) rangkuman, 13) evaluasi, 14) daftar pustaka, dan 15) kunci jawaban.

\section{DESKRIPSI TEORITIK DAN PENGEMBANGAN HIPOTESIS}

\section{Konsep Belajar}

Belajar merupakan salah satu faktor yang memengaruhi dan berperan penting dalam pembentukan pribadi dan perilaku individu (Rusman, 2013: 85). Perubahan sikap individu dalam bentuk perilaku dan kepribadian individu berlangsung dalam kegiatan belajar. Hal ini senada juga dengan yang disampaikan oleh Trianto (2009: 19), bahwa belajar diartikan sebagai proses perubahan perilaku tetap dari belum tahu menjadi tahu, dari tidak paham menjadi paham, dari kurang terampil menjadi lebih terampil, dan dari kebiasaan lama menjadi kebiasaan baru, serta bermanfaat bagi lingkungan maupun individu itu sendiri.

\section{Hasil Belajar dan Faktor-faktor yang Mempengaruhinya}

Hasil belajar merupakan bagian yang tidak terpisahkan dalam proses pembelajaran. Menurut Rusman (2013: 123) menyatakan bahwa hasil belajar adalah sejumlah pengalaman yang diperoleh siswa yang mencakup ranah kognitif, afektif, dan psikomotorik. Hal tersebut juga senada dengan pendapat Syah dalam Karwati dan Priansa (2014: 214), mengungkapkan bahwa hasil belajar ideal meliputi segenap ranah psikologis yang berubah sebagai akibat pengalaman dan proses belajar peserta didik. Belajar tidak hanya penguasaan konsep teori mata pelajaran saja, tetapi juga penguasaan kebiasaan, persepsi, kesenangan, minat bakat, penyesuaian sosial, macam-macam keterampilan, cita-cita, keinginan, dan harapan. Hasil belajar merupakan satu kesatuan penilaian dari kegiatan belajar siswa, baik dari ranah afektif, kognitif, dan psikomotorik.

Faktor-faktor yang memengaruhi belajar ada beberapa jenis, tetapi dapat digolongkan menjadi dua golongan, yaitu faktor Interen berupa faktor jasmaniah, faktor psikologis, faktor kelelahan dan faktor Eksteren berupa faktor keluarga, faktor sekolah, faktor masyarakat (Slameto, 2003: 54-60).

\section{Model Pembelajaran}

Menurut Hosnan (2014: 337) yang mendefinisikan model pembelajaran adalah kerangka konseptual/operasional, yang melukiskan prosedur yang sistematis dalam mengorganisasikan pengalaman belajar untuk mencapai tujuan belajar tertentu dan berfungsi sebagai pedoman bagi para pengajar dalam merencanakan, dan melaksanakan aktivitas pembelajaran. Model pembelajaran yang dikembangkan oleh para ahli, di antaranya terdapat model pembelajaran kooperatif, model pembelajaran konteksual, model pembelajaran inquiry, model pembelajaran quantum, model pembelajaran terpadu, dan model Problem Based Learning (PBL). Banyaknya model pembelajaran tidak berarti semua pengajar bisa menerapkan untuk setiap mata pelajaran karena tidak semua model cocok untuk setiap topik atau mata pelajaran. Pengajar harus mempertimbangkan dalam memilih model pembelajaran yang cocok dan sesuai dengan topik mata pelajaran yang akan diberikan. Menurut Karwati dan Priansa (2014: 248) yang menyatakan bahwa terdapat beberapa aspek yang perlu dipertimbangkan dalam pemilihan model pembelajaran di anta- 
ranya hasil (outcome), isi materi (content), dan proses (process). Beberapa hal yang perlu dipertimbangkan dalam memilih model/strategi pembelajaran yaitu: 1) tujuan pembelajaran yang ingin dicapai, 2) sifat bahan/materi ajar, 3) kondisi siswa, dan 4) ketersediaan saranaprasarana belajar (Sugiyanto, 2009: 4).

\section{Modul Pembelajaran}

Modul merupakan salah satu bentuk bahan ajar yang dikemas secara utuh dan sistematis, di dalamnya memuat seperangkat pengalaman belajar yang terencana dan didesain untuk membantu peserta didik menguasai tujuan belajar yang spesifik (Daryanto, 2013: 9). Sedangkan menurut Surahman dalam Prastowo (2012: 105), modul adalah satuan program pembelajaran terkecil yang dapat dipelajari oleh peserta didik secara perseorangan (self instructional).

Modul merupakan suatu paket dalam program pengajaran yang terdiri dari beberapa komponen yang berisi tujuan belajar, metode belajar, alat atau media serta sistem evaluasi. Hal ini sejalan dengan pendapat Hamdani (2011:219220) bahwa modul adalah sarana pembelajaran dalam bentuk tertulis, atau cetak yang disusun secara sistematis, memuat materi pembelajaran, metode, tujuan pembelajaranberdasarkan kompetensi, petunjuk kegiatan belajar mandiri (self instructional), dan memberikan kesempatan kepada siswa untuk menguji diri sendiri melalui latihan yang disajikan dalam modul tersebut. Tujuan penyusunan modul adalah menyediakan bahan ajar yang sesuai dengan tuntutan kurikulum dengan mempertimbangkan kebutuhan siswa, yakni bahan ajar yang sesuai dengan karakteristik materi ajar dan karakteristik siswa, serta setting atau latar belakang lingkungan sosialnya (Hamdani, 2011: 220).

Menurut Smaldino, Lowther, dan Russel (2014: 280) menyatakan bahwa terdapat keuntungan dan keterbatasan modul yaitu keuntungan modul diantaranya menentukan kecepatan sendiri, kemasan total, tervalidasi, sedangkan keterbatasan modul di antaraya kualitas modul, kehilangan fleksibilitas, integrasi kurikuler.

\section{Pengembangan Modul}

Hal pertama yang perlu dilakukan dalam pengembangan suatu modul adalah dengan menetapkan desain modul atau rancangan modul pembelajaran tersebut. Kedudukan desain dalam pengembangan modul adalah sebagai salah satu komponen prinsip pengembangan yang mendasari dan memberi arah teknik dan tahapan penyusunan modul. Menurut Oemar dalam Daryanto (2013: 11), mendefinisikan desain adalah suatu petunjuk yang memberi dasar, arah, tujuan, dan teknik yang ditempuh dalam memulai dan melaksanakan suatu kegiatan.

Berdasarkan desain modul yang telah dikembangkan, selanjutnya dilakukan penyusunan modul. Menurut Daryanto (2013: 11-12), menyatakan bahwa proses penyusunan modul terdiri dari tiga tahapan pokok yaitu menetapkan strategi pembelajaran dan media pembelajaran yang sesuai, memproduksi atau mewujudkan fisik modul, dan mengembangkan perangkat penilaian.

Menurut Daryanto (2013: 31) yang menyatakan bahwa pengembangan bahan ajar mandiri atau bisa disebut modul, langkah-langkah yang ditempuh adalah perencanaan, penulisan, review dan revisi, dan yang terakhir finalisasi. Selain itu, sebuah modul dapat dikatakan sebagai bahan ajar dimana pembacanya dapat belajar mandiri. Pengembangan modul harus diperhatikan prinsip serta analisis kebutuhan dan kondisi lingkungannya supaya modul dapat benar-benar bermanfaat bagi siswa. Pengembangan modul harus menarik sehingga mampu meningkat motivasi siswa dan efektif dalam mencapai kompetensi yang diharapkan.

\section{Pembelajaran Guided Inquiry}

Belajar merupakan suatu kebiasaan yang memberikan perubahan perilaku siswa sebagai akibat adanya pengalaman dalam pembelajaran. Guru harus mampu memberikan pengalaman yang variatif dalam setiap pembelajaran supaya memberikan pengalaman baru serta mem- 
buat kegiatan belajar lebih menarik dan menantang. Guru harus mampu mengelola dan memaksimalkan komponen-komponen yang dibutuhkan dalam menunjang kualitas pembelajaran. Oleh karena itu, guru harus mampu menerapkan strategi dan metode belajar agar pembelajaran menjadi lebih kreatif dan tidak membosankan. Strategi merupakan usaha untuk memperoleh kesuksesan dan keberhasilan dalam mencapai tujuan (Sujarwo, 2011: 81).

Salah satu strategi pembelajaran yang dapat digunakan oleh guru untuk membuat siswa terlibat secara aktif dalam pembelajaran adalah dengan strategi pembelajaran guided inquiry. Menurut Jauhar (2011: 69), definisi pendekatan guided inquiry yaitu pendekatan inquiry dimana guru membimbing siswa melakukan kegiatan dengan memberi pertanyaan awal dan mengarahkan pada suatu diskusi. Pembelajaran dengan pendekatan ini memposisikan guru sebagai fasilitator dalam membimbing siswa untuk melaksanakan kegiatan pembelajaran yang berlangsung dalam kelas. Menurut Jauhar (2011: 75) yang menyatakan bahwa tujuan utama pembelajaran berbasis inquiry menurut National Research Council adalah a) mengembangkan keinginan dan motivasi siswa untuk mempelajari prinsip dan konsep sains, b) mengembangkan keterampilan ilmiah siswa sehingga mampu bekerja seperti layaknya seorang ilmuan, c) membiasakan siswa bekerja keras untuk memperoleh pengetahuan.

Menurut Moore dalam Sujarwo (2011: 87) yang menyatakan bahwa pembelajaran inquiry memiliki tiga tingkatan yaitu: 1) guided inquiry, 2) modified inquiry, dan 3) open inquiry.

Menurut Hosnan (2014: 341) yang menyatakan bahwa pembelajaran inquiry merupakan rangkaian kegiatan pembelajaran yang menekankan pada proses berpikir kritis dan analitis untuk mencari dan menemukan sendiri jawaban dari suatu masalah yang dipertanyakan. Menurut Hamdani (2011: 183) yang menyatakan bahwa model inquiry memiliki beberapa keuntungan, yaitu Siswa memiliki kesempatan un- tuk mengemukakan ide atau gagasan yang dimilikinya, siswa mulai diajarkan untuk menganalisis dan mencari kebenaran dari suatu masalah yang sedang dibahas, mampu berpikir sistematis, terarah, dan mempunyai tujuan yang jelas, siswa mampu berpikir induktif, deduktif, dan empiris rasional sehingga hal ini akan menyebabkan siswa memiliki kemampuan dalam penalaran formal yang baik.

Menurut Moore dalam Sujarwo (2011: 89) menyatakan bahwa prosedur pembelajaran inquiry meliputi, 1) identifikasi masalah (problem identification), 2) mengumpulkan data (data collection), 3) merumuskan hipotesis atau asumsi (formulation of hyphotesis), 4) analisis data dan materi (analysis data and material), 5) uji hipotesis, dan 6) membuat kesimpulan.

\section{Pengembangan Hipotesis}

Berdasarkan pemaparan di atas, hipotesis dalam penelitian ini yaitu (1) Siswa yang belajar dengan menggunakan modul pembelajaran ekonomi berbasis guided inquiry mendapatkan hasil belajar yang lebih tinggi, dan (2) Modul pembelajaran ekonomi berbasis guided inquiry efektif digunakan dalam proses pembelajaran dan mampu meningkatkan hasil belajar siswa.

\section{METODOLOGI PENELITIAN}

\section{Tempat dan Waktu Penelitian}

Tempat penelitian merupakan suatu sumber untuk mendapatkan data-data yang dibutuhkan mengenai masalah yang akan diteliti. Penelitian ini dilakukan di SMA Muhammadiyah 1 Karanganyar yang beralamat di Jln. Brigjen Slamet Riyadi Karanganyar Ska. Penelitian pengembangan ini akan dilaksanakan dari bulan September 2015 sampai selesai.

\section{Jenis Penelitian}

Jenis penelitian ini berupa penelitian pengembangan (Research and Development). Metode penelitian dan pengembangan dapat diartikan sebagai cara ilmiah untuk meneliti, merancang, memproduksi, dan menguji validitas produk yang telah dihasilkan (Sugiyono, 2015: 30). Pro- 
sedur pengembangan merupakan langkahlangkah yang ditempuh dalam pengembangan ini mengacu pada model tahapan penelitian metode Research and Development (R\&D). Prosedur pengembangan dalam penelitian ini mengacu pada prosedur pengembangan Borg and Gall yang dimodifikasi sampai pada tahap kedelapan.

\section{Populasi dan Teknik Pengambilan Sampel}

Populasi dalam penelitian ini adalah siswa kelas X SMA Muhammadiyah 1 Karanganyar tahun pelajaran 2015/2016 yang berjumlah 554 siswa. Teknik pengambilan sampel dalam penelitian ini adalah probality random sampling, yaitu teknik pengambilan sampel yang memberikan peluang yang sama bagi setiap unsur (anggota) populasi untuk dipilih menjadi anggota sampel. Instrumen pengumpulan data dalam penelitian ini terdiri dari lembar validasi, angket, tes, dan lembar observasi.

\section{Teknik Analisis Data}

Analisis data digunakan untuk mengolah data yang diperoleh setelah mengadakan penelitian, sehingga diperoleh kesimpulan tentang objek yang diteliti dalam keadaan yang sebenarnya. Analisis data dalam penelitian ini meliputi (1) analisis data deskriptif yang erdiri dari analisis data validitas modul dari ahli dan analisis data angket dari siswa, (2) analisis statistik inferensial yang terdiri dari (a) uji pasyarat analisis berupa uji normalitas dan homogenitas, dan (b) uji keefektifan yang menggunakan T-test dua sampel independen.

\section{HASIL DAN PEMBAHASAN}

Hasil

Uji keefektifan sekaligus uji hipotesis dalam penelitian ini menggunakan uji-t. Pengujian hipotesis dengan uji-t digunakan untuk menguji keefektifan modul pembelajaran ekonomi berbasis guided inquiry. Kriteria yang digunakan dalam pengambilan hipotesis adalah tingkat $\alpha=$ 0,05. H0 ditolak jika signifikansi probabilitas (sig) $<\alpha(0,050)$ dan jika taraf signifikansi probabilitas (sig) $>$ a $(0,050)$ maka H0 tidak ditolak. Hasil uji keefektifan sekaligus uji hipotesis dalam penelitian ini adalah sebagai berikut.

\begin{tabular}{|c|l|c|c|c|c|}
\hline \multicolumn{6}{|c|}{ Tabel 1.1 } \\
Uft-T Pretest Kelompok Eksperimen dan Kontrol \\
\hline \multirow{5}{|c|}{ Group Statistics } \\
\hline \multirow{2}{*}{ Nilai } & Kelompok & N & Mean & $\begin{array}{c}\text { Std. } \\
\text { Deviation }\end{array}$ & $\begin{array}{c}\text { Std. Error } \\
\text { Mean }\end{array}$ \\
\cline { 2 - 6 } & Eksperimen & 39 & 52.244 & 7.0430 & 1.1278 \\
\hline & 42 & 54.893 & 7.3663 & 1.1366 \\
\hline
\end{tabular}

Berdasarkan tabel 1.1 di atas, dapat dilihat bahwa nilai mean atau nilai rata-rata pretest kelompok eksperimen adalah 52,24 dan nilai mean kelompok kontrol adalah 54,89. Hal ini menunjukkan bahwa kelompok kontrol lebih unggul dari pada kelompok eksperimen, namun untuk membuktikan apakah terdapat perbedaan yang signifikan antara hasil belajar kelompok kontrol dan kelompok eksperimen disajikan dalam tabel di bawah ini.

\begin{tabular}{|c|c|c|c|c|c|c|c|c|c|c|}
\hline \multicolumn{11}{|c|}{ Independent Samples Test } \\
\hline & & \multicolumn{2}{|c|}{$\begin{array}{l}\text { Levene's Test for } \\
\text { Equality of Variances }\end{array}$} & \multicolumn{7}{|c|}{ t-test for Equality of Means } \\
\hline & & \multirow[b]{2}{*}{$\mathbf{F}$} & \multirow[b]{2}{*}{ Sig } & \multirow[b]{2}{*}{$\mathbf{T}$} & \multirow[b]{2}{*}{ df } & \multirow[b]{2}{*}{$\begin{array}{c}\text { Sig. } \\
\text { (2-tailed) }\end{array}$} & \multirow[b]{2}{*}{$\begin{array}{c}\text { Mean } \\
\text { Difference }\end{array}$} & \multirow[b]{2}{*}{$\begin{array}{l}\text { Std. Error } \\
\text { Difference }\end{array}$} & \multicolumn{2}{|c|}{$\begin{array}{l}95 \% \text { Confidence } \\
\text { Interval of the } \\
\text { Difference }\end{array}$} \\
\hline & & & & & & & & & Lower & Upper \\
\hline \multirow{2}{*}{ Nilai } & $\begin{array}{l}\text { Equal variances } \\
\text { assumed }\end{array}$ & .010 & .923 & 1.652 & 79 & .103 & 2.6493 & 1.6039 & -.5432 & 5.8418 \\
\hline & $\begin{array}{l}\text { Equal variances } \\
\text { not assumed }\end{array}$ & & & 1.655 & 78.928 & .102 & 2.6493 & 1.6012 & -.5379 & 5.8364 \\
\hline
\end{tabular}


Berdasarkan tabel 1.2 di atas, dapat dilihat bahwa nilai signifikansi uji-t adalah 0,103 . Nilai signifikansi tersebut lebih besar dari 0,05 yang berarti bahwa $\mathrm{H}_{0}$ tidak ditolak serta nilai $\mathrm{t}_{\text {hitung }}$ adalah sebesar 1,652< $t_{\text {tabel }}$ yaitu sebesar 1,98. Hal ini menunjukkan tidak ada perbedaan yang signifikan rata-rata hasil belajar siswa antara kelompok kontrol dan kelompok ekperimen.

\begin{tabular}{|l|l|c|c|c|c|}
\hline \multicolumn{6}{|l|}{ Tabel 1.3 } \\
\hline \multicolumn{6}{|c|}{ Uji-t Posttest Kelompok Eksperimen dan Kontrol } \\
\hline \multicolumn{7}{|c|}{ Group Statistics } \\
\hline \multirow{2}{*}{ Nilai } & Kelompok & N & Mean & $\begin{array}{c}\text { Std. } \\
\text { Deviation }\end{array}$ & $\begin{array}{c}\text { Std. Error } \\
\text { Mean }\end{array}$ \\
\cline { 2 - 6 } & Kontrol & 42 & 82.17521 & 6.834718 & 1.094431 \\
\hline \multicolumn{6}{|c|}{ Sumber: Hasil pengolahan data tahun 2016} \\
\hline
\end{tabular}

Berdasarkan tabel 1.3 di atas, dapat dilihat bahwa nilai mean posttest kelompok eksperimen adalah 82,175 dan nilai mean kelompok kontrol adalah 70,448. Hal ini menunjukkan bahwa kelompok eksperimen lebih unggul dari pada kelompok kontrol. Namun untuk membuktikan apakah terdapat perbedaan yang signifikan antara hasil belajar kelompok kontrol dan kelompok eksperimen disajikan dalam tabel dibawah ini.

Berdasarkan tabel 1.4 di bawah, dapat dilihat bahwa nilai signifikansi uji-t adalah 0,000. Nilai signifikansi tersebut kurang dari 0,05 yang berarti bahwa $\mathrm{H}_{1}$ tidak ditolak serta nilai thitung adalah sebesar 7,853> tabel yaitu sebesar 1,99. Hal ini menunjukkan terdapat perbedaan yang signifikan rata-rata nilai hasil belajar siswa antara kelompok kontrol dan kelompok eksperimen. Hal tersebut menunjukkan bahwa peningkatan hasil belajar kelompok eksperimen lebih baik dari pada kelompok kontrol.

\section{PEMBAHASAN}

1. Kevalidan Modul Pembelajaran Ekonomi Berbasis Guided inquiry

a) Validasi ahli media

Hasil penilaian modul pembelajaran ekonomi berbasis guided inquiry oleh ahli media pembelajaran yaitu dari indikator pada ukuran modul pembelajaran, desain sampul modul pembelajaran, dan desain isi modul pembelajaran. Skor total persentase seluruh aspek penilaian dari hasil validasi ahli media adalah 98,28\% dengan kriteria sangat baik. Hal tersebut menggambarkan bahwa modul pembelajaran ekonomi berbasis guided inquiry efektif dan efisien digunakan dalam proses pembelajaran serta menarik untuk digunakan oleh siswa. Modul pembelajaran ekonomi berbasis guided inquiry memberikan karakteristik yang komunikatif, memikat, mudah dipahami, dan penggunaan gambar relevan dengan konsep dan ukuran proporsional, serta memiliki daya tarik untuk siswa mempelajari modul pembelajaran sehingga mampu untuk mendorong rasa ingin tahu siswa untuk

\begin{tabular}{|c|c|c|c|c|c|c|c|c|c|c|}
\hline \multicolumn{11}{|c|}{ ples Test } \\
\hline & & \multicolumn{2}{|c|}{$\begin{array}{l}\text { Levene's Test for } \\
\text { Equality of Variances }\end{array}$} & \multicolumn{7}{|c|}{ t-test for Equality of Means } \\
\hline & & \multirow[b]{2}{*}{$\mathbf{F}$} & \multirow[b]{2}{*}{ Sig } & \multirow[b]{2}{*}{$\mathbf{T}$} & \multirow[b]{2}{*}{ df } & \multirow[b]{2}{*}{$\begin{array}{c}\text { Sig. } \\
\text { (2-tailed) }\end{array}$} & \multirow[b]{2}{*}{$\begin{array}{c}\text { Mean } \\
\text { Difference }\end{array}$} & \multirow[b]{2}{*}{$\begin{array}{l}\text { Std. Error } \\
\text { Difference }\end{array}$} & \multicolumn{2}{|c|}{$\begin{array}{c}95 \% \text { Confidence } \\
\text { Interval of the } \\
\text { Difference }\end{array}$} \\
\hline & & & & & & & & & Lower & Upper \\
\hline \multirow{2}{*}{ Nilai } & $\begin{array}{l}\text { Equal variances } \\
\text { assumed }\end{array}$ & .538 & .465 & 7.864 & 79 & .000 & 11.726801 & 1.491111 & 8.758819 & 14.694783 \\
\hline & $\begin{array}{l}\text { Equal variances } \\
\text { not assumed }\end{array}$ & & & 7.853 & 78.013 & .000 & 11.726801 & 1.493208 & 8.754061 & 14.699541 \\
\hline \multicolumn{11}{|c|}{ Sumber: Hasil pengolahan data tahun 2016} \\
\hline
\end{tabular}


giat dalam belajar. Berdasarkan validasi ahli media pembelajaran, bahwa modul pembelajaran ekonomi berbasis guided inquiry tersebut valid dan dapat digunakan untuk pembelajaran.

b) Validasi ahli materi

Hasil yang diperoleh dari validasi ahli materi bahwa hasil penilaian materi dalam modul pembelajaran ekonomi berbasis guided inquiry oleh ahli media pembelajaran yaitu aspek kelayakan isi, kelayakan penyajian, aspek pendekatan pembelajaran, aspek konsep pembelajaran, aspek proses evaluasi mendapatkan hasil $83,87 \%$ dengan kriteria sangat baik. Hal tersebut menggambarkan bahwa materi dalam modul pembelajaran ekonomi ini sudah jelas tujuan pembelajarannya dan relevansi tujuan pembelajaran dengan silabus/kurikulum dikatakan baik dalam memberi motivasi belajar untuk siswa.

c) Validasi praktisi

Hasilpenilaianmodulpembelajaran ekonomi berbasis guided inquiry oleh guru ekonomi di SMA Muhammadiyah 1 Karanganyar yaitu dari aspek penilaian bahasa, aspek kelayakan isi, aspek kelayakan penyajian, aspek penyajian pembelajaran guided inquiry, dan aspek manfaat belajar, mendapatkan skor total dengan persentase 95,90\% dengan kriteria sangat baik. Hal tersebut menggambarkan bahwa modul pembelajaran ekonomi berbasis guided inquiry sudah sesuai dengan sumber belajar yang dibutuhkan dalam pembelajaran, dan memudahkan siswa dalam menguasai materi pelajaran. Oleh karena itu, praktisi memberikan kesimpulan bahwa pengembangan modul pembelajaran ekonomi berbasis guided inquiry ini valid dan dapat digunakan. d) Validasi bahasa

Hasilpenilaianmodulpembelajaran ekonomi berbasis guided inquiry oleh ahli bahasa yaitu persentase indikator penilaian kelugasan, komunikatif, kesesuaiaan dengan tingkat perkembangan siswa, keruntutan dan keterpaduan alur pikir pada modul pembelajaran ekonomi berbasis guided inquiry, penggunaan istilah, simbol atau ikon mendapatkan skor total $100 \%$ dengan kriteria sangat baik. Hal tersebut menggambarkan bahwa modul pembelajaran ekonomi berbasis guided inquiry sudah memenuhi kaidah penggunaan bahasa yang baik dan benar. Oleh karena itu, penilaian ahli bahasa menyimpulkan bahwa modul pembelajaran ekonomi berbasis guided inquiry layak digunakan tanpa revisi.

2. Kelayakan Modul Pembelajaran Ekonomi Berbasis Guided Inquiry

Hasil yang diperoleh dari uji coba terbatas mengenai modul pembelajaran ekonomi berbasis guided inquiry pada siswa kelas X semester genap melalui penerapan modul pembelajaran ekonomi berbasis guided inquiry dalam kegiatan belajar siswa yang dilakukan oleh peneliti dan guru bahwa modul pembelajaran tersebut dapat digunakan dalam pembelajaran dan sesuai dengan langkah-langkah pembelajaran yang sudah ditentukan. Berdasarkan hasil penilaian angket mengenai modul pembelajaran ekonomi berbasis guided inquiry yang dibagikan pada saat tahap uji coba bahwa skor hasil angket tanggapan siswa dalam memberikan penilaian terkait aspek tampilan pada modul pembelajaran ekonomi berbasis guided inquiry mendapatkan skor mencapai $88,00 \%$ dengan kriteria sangat baik, untuk aspek penyajian materi mendapatkan skor nilai $81,17 \%$ dengan kriteria sangat baik, untuk aspek pembelajaran guided inquiry 
mendapatkan skor mencapai 81,48\%, dan aspek manfaat mendapatkan skor nilai $82,67 \%$, sehingga dapat disimpulkan bahwa siswa memberikan tanggapan yang positif terhadap modul pembelajaran ekonomi berbasis guided inquiry dengan nilai total kelayakan mencapai 82,99\% dengan kategori sangat baik. Hal ini berarti modul pembelajaran ekonomi berbasis guided inquiry valid untuk digunakan.

3. Keefektifan Modul Pembelajaran Ekonomi Berbasis Guided Inquiry

Berdasarkan penilaian kognitif, afektif, dan psikomotorik siswa menunjukan bahwa penggunaan modul pembelajaran ekonomi berbasis guided inquiry sangat efektif ditunjukkan dengan hasil rata-rata penilaian kognitif sebesar 83,91, hasil ratarata penilaian afektif sebesar 80,35 dan hasil rata-rata penilaian psikomotorik sebesar 82,17 . Keefektifan tersebut diperkuat dengan hasil uji keefektifan mengenai modul pembelajaran ekonomi berbasis guided inquiry yang efektif meningkatkan hasil belajar siswa. Pada tahap uji luas yang didapatkan siswa saat dilakukan pretest mendapatkan hasil dengan rata-rata nilai sebesar 66,33 dan setelah melakukan pembelajaran dengan menggunakan modul pembelajaran ekonomi berbasis guided inquiry terdapat kenaikan rata-rata nilai sebesar yaitu 77,44 . Hal ini menunjukkan bahwa adanya peningkatan hasil belajar siswa. Pada tahap uji lapangan ketika di lakukan pretest siswa memperoleh rata-rata nilai sebesar 52,24 dan setelah melakukan proses pembelajaran yang menerapkan modul pembelajaran ekonomi berbasis guided inquiry terdapat kenaikan nilai rata-rata yaitu menjadi 82,17. Berdasarkan perhitungan statistik menunjukkan terdapat perbedaan yang signifikan nilai rata-rata hasil tes belajar pretest (sebelum tindakan) dan posttest (setelah tindakan), sehingga $\mathrm{H}_{1}$ diterima dan $\mathrm{H}_{0}$ ditolak yang menunjukkan bahwa modul pembelajaran ekonomi berbasis guided inquiry efektif untuk meningkatkan hasil belajar siswa.

\section{KESIMPULAN DAN SARAN KESIMPULAN}

Berdasarkan hasil penelitian maka dapat ditarik kesimpulan sebagai berikut.

1. Pengembangan modul pembelajaran ekonomi berbasis guided inquiry untuk meningkatkan hasil belajar siswa kelas X di SMA Muhammadiyah 1 Karanganyar menghasilkan modul pembelajaran ekonomi berbasis guided inquiry yang diawali dengan studi pendahuluan untuk menganalisis kebutuhan akan modul pembelajaran ekonomi kemudian direncanakan pengembangan dalam bentuk desain awal. Setelah itu, desain awal tersebut divalidasi oleh ahli materi, ahli media, dan ahli praktisi untuk mengetahui kelayakan modul pembelajaran ekonomi berbasis guided inquiry. Pengembangan modul pembelajaran ekonomi berbasis guided inquiry juga telah melalui tahap uji kelayakan yang direvisi berdasarkan masukan dari siswa dan diskusi dengan guru. Modul pembelajaran ekonomi berbasis guided inquiry telah dinyatakan valid dan layak digunakan menurut ahli media dengan persentase 98,28\% dengan kategori sangat baik, menurut ahli materi dengan persentase $93,85 \%$ degan kategori sangat baik, dan menurut ahli praktisi dengan persentase 95,90\% dengan kategori sangat baik. Oleh sebab itu, dapat disimpulkan bahwa modul pembelajaran ekonomi berbasis guided inquiry valid dan layak untuk digunakan dalam proses pembelajaran sebagai upaya meningkatkkan hasil belajar siswa. Kevalidan tersebut juga didukung dengan hasil uji kelayakan pada uji terbatas yang mendapatkan hasil $82,99 \%$ dengan kategori sangat baik dan uji kelayakan pada uji luas mendapatkan hasil 85,59\% dengan kriteria sangat baik.

2. Modul pembelajaran ekonomi berbasis guided inquiry efektif untuk meningkatkan 
hasil belajar siswa. Hal tersebut dapat dilihat dari hasil penilaian kognitif, afektif, dan psikomotorik yang memperoleh hasil ratarata penilaian kognitif sebesar 83,91 dengan kriteria sangat baik, hasil rata-rata peneliaian afektif sebesar 80,38 dengan kriteria baik dan hasil rata-rata penilaian psikomotorik sebesar 82,23 dengan kriteria sangat baik, hal ini menunjukan bahwa penggunaan modul pembelajaran ekonomi berbasis guided inquiry pada siswa memberikan respon yang baik dan positif. Selain itu juga didukung dari penilaian hasil belajar pada uji coba luas yang didapatkan siswa pada saat pretest dengan ratarata nilai sebesar 66,33 dan setelah melakukan pembelajaran dengan menggunakan modul pembelajaran ekonomi berbasis guided inquiry terdapat kenaikan rata-rata nilai sebesar yaitu 77,44. Hal ini menunjukkan bahwa adanya peningkatan hasil belajar siswa, kemudian diperkuat dengan hasil uji lapangan yaitu pada saat pretest siswa memperoleh rata-rata nilai sebesar 52,24 dan setelah melakukan pembelajaran menggunakan modul pembelajaran ekonomi berbasis guided inquiry terdapat kenaikan rata-rata nilai sebesar yaitu 82,17 . Penggunaan modul pembelajaran ekonomi berbasis guided inquiry sangat efektif dan menarik, terlihat dari siswa yang banyak termotiviasi untuk mempelajari modul pembelajaran dalam kegiatan belajarnya. Berdasarkan perhitungan statistik menunjukkan terdapat perbedaan yang signifikan nilai rata-rata hasil tes belajar pretest (sebelum tindakan) dan posttest (setelah tindakan), sehingga $\mathrm{H}_{1}$ diterima dan $\mathrm{H}_{0}$ ditolak yang menunjukkan bahwa modul pembelajaran ekonomi berbasis guided inquiry efektif untuk meningkatkan hasil belajar siswa.

\section{Implikasi}

1. Pengembangan modul pembelajaran dibuat disesuaikan dengan kriteria pembuatan bahan ajar dan melalui tahapan pengembangan uji coba dan penilaiaan modul baik dari ahli maupun siswa yang menghasilkan sumber belajar berupa modul pembelajaran ekonomi berbasis guided inquiry.

2. Pengembangan modul pembelajaran ekonomi berbasis guided inquiry untuk meningkatkan hasil belajar siswa yaitu dari sisi siswa, dapat menciptakan suasana belajar yang efektif karena siswa aktif dalam melakukan kegiatan belajar dan siswa juga terdorong untuk melakukan diskusi dengan teman-teman kelasnya. Modul pembelajaran ini juga dapat memberikan informasi secara kontekstual yang sesuai dengan kehidupan sehari-hari yang tidak bisa diamati secara langsung oleh siswa sehingga membantu siswa memahami konsep materi secara menyeluruh. Selain itu, dari sisi guru yaitu guru harus lebih kreatif dalam penuangan ide dan gagasan dalam penyampaian materi, guru dituntut harus bisa menggunakan dan mengembangkan sumber belajar bagi siswa sehingga dapat menciptakan pembelajaran yang menarik, efektif, efisien, dan kondusif sehingga pembelajaran dapat diterima siswa dengan baik dan dapat meningkatkan hasil belajar siswa.

\section{SARAN}

a. Kepada pihak sekolah harus menyediakan sumber belajar yang memadai sehingga dapat meningkatkan kreativitas guru dan siswa dalam pembelajaran serta dapat meningkatkan hasil belajar ekonomi, dan sekolah hendaknya selalu merespon terhadap perkembangan zaman dalam memberikan fasilitas kepada guru untuk kreatif dan inovatif dalam mengembangkan sumber belajar bagi siswa.

b. Kepada guru, guru harus mengembangkan keprofesian dengan mengikuti pelatihan, workshop pendidikan, sebagai upaya peningkatan kualitas pengembangan diri dan guru mampu membuat karya-karya inovatif pengembangan sumber belajar yang dapat memberikan kontribusi dalam peningkatan 
kualitas pembelajaran, dan guru dapat mengembangkan keberlanjutan modul pembelajaran ekonomi berbasis guided inquiry yang telah dikembangkan peneliti untuk diperbaharui dan dikaji ulang agar materinya disesuaikan dengan perkembangan zaman.

c. Kepada siswa, Siswa harus aktif dalam hal mencari dan mempelajari secara mandiri sumber belajar yang tersedia karena pembelajaraan saat ini berorientasi pada siswa dan guru hanya berperan sebagai fasilitator. Siswa diharapkan mampu menguasai materi berdasarkan kemampuannya dalam berpikir dan membangun sendiri pengetahuan yang dimilikinya.

d. Kepada peneliti lain, penelitian ini dapat digunakan sebagai acuan untuk penelitian yang sejenis dengan mengembangkan modul pembelajaran, penelitian ini juga dapat dikembangkan dengan menambah variabel bebas lain dengan model pembelajaran lain yang seimbang.

\section{DAFTAR PUSTAKA}

Daryanto. 2013. Menyusun Modul : Bahan Ajar Untuk Persiapan Guru Mengajar. Yogyakarta: Gava Media.

Hamdani. 2011. Strategi Belajar dan Mengajar. Bandung: Pustaka Setia.

Hosnan. 2014. Pendekatan Saintifik Kontekstual dalam Pembelajaran Abad 21. Bogor: Ghalia Indonesia.

Jauhar, Mohammad. 2011. Implementasi Paikem dari Behavioristik Sampai Konstruktivistik: Sebuah Pengembangan Pembelajaran Berbasis Contextual Teaching and Learning (CTL). Jakarta: Prestasi Pustaka.

Prastowo, Andi. 2012. Panduan Kreatif Membuat Bahan Ajar Inovatif. Yogyakarta: Diva Press.

Rusman. 2013. Belajar dan Pembelajaran Berbasis Komputer. Bandung: Alfabeta.

Slameto. 2003. Belajar dan Faktor-faktor yang Mempengaruhinya. Jakarta: Rineka Cipta.

Smaldino, Sharon E., Lowther, Deborah L., dan Russell, James D. 2014. Instructional Technology and Media For Learning (Teknologi Pembelajaran dan Media Untuk Belajar). Jakarta: Kencana Prenada Media Group.

Sugiyanto. 2009. Model-Model Pembelajaran Inovatif. Surakarta: FKIP UNS.

Sujarwo. 2011. Model-Model Pembelajaran: Suatu Strategi Mengajar. Yogyakarta: Venus Gold Press.

Trianto. 2009. Mendesain Model Pembelajaran Inovatif-progesif. Jakarta: Kencana Prenada Media Group.

Karwati, E., dan Priansa, Donni J. 2014. Manajemen Kelas (Classroom Management): Guru Profesional yang Inspiratif, Kreatif, Menyenangkan, dan Berprestasi. Bandung: Alfabeta. 